\title{
ISLAMIC CENTER DAN PERAN KEKUASAAN DALAM KONSTRUKSI IDENTITAS ISLAM DI LOMBOK
}

\author{
Mustain \\ Universitas islam Negeri (UIN) Mataram, Indoensia \\ mustain@uinmataram.ac.id
}

\begin{abstract}
Abstrak
Era reformasi membawa kebebasan dan keterbukaan dalam kehidupan sosial, politik, dan keagamaan bagi bangsa Indonesia. Kondisi ini memicu munculnya kontestasi identitas agama dalam kehidupan sosial di tingkat nasional maupun regional. Prosesnya tidak hanya dilakukan masyarakat, tetapi juga melibatkan aktor-aktor yang di antaranya adalah para gubernur, bupati, dan wali kota. Wujud kontestasi itu antara lain berupa konstruksi identitas regional dan lokal yang menggunakan simbol-simbol agama. Di wilayah Nusa Tenggara Barat, khususnya di pulau Lombok konstruksi identitas Islam diwujudkan dalam bentuk pembangunan Islamic Center di kota Mataram. Dengan menggunakan pendekatan kualitatif, hasil penelitian ini menunjuk.kan bahwa ada peran yang sangat besar dari sang gubernur, yaitu Dr. TGH. Zainul Madjdi atau Tuan Guru Bajang (TGB) dalam pembangunan Islamic Center di Mataram Lombok. Peran itu diwujudkan dalam berbagai bentuk, yaitu dukungan dana dalam APBD NTB tahun 2011-2014, penggalangan dana masyarakat, dan peran dalam manajemen dan pengelolaan. Berkat komitmen yang kuat dari TGB, gagasan untuk membangun Islamic Center yang telah bergulir semenjak kepemimpinan tiga gubernur sebelumnya dapat diwujudkan.
\end{abstract}


Komintennya itu diwnjudkan dengan dukungan dana dari $A P B D$ NTB sepanjang periode pertama kepemimpinannya. Selanjutnya untuke menjamin keberlangsungannya, TGB juga membentuk. UPT Islamic Center sebagai unit yang bertanggung jawab mengelola Islamic Center.

Keywords: konstruksi identitas, Islamic Center, peran gubernur.

\section{A. Pendahuluan}

Semenjak diresmikan penggunaannya oleh Gubernur NTB, TGH. Zainul Majdi, pada tanggal 12 September 2016, tepatnya setelah pelaksanaan shalat Idul Adha 10 Dzulhijjah 1437 H, keberadaan Islamic Center (IC) dengan Masjid Hubbul Wathan di dalamnya telah menarik perhatian masyarakat secara luas. Hal itu tidak terlepas dari keberadaannya yang sering menjadi pusat kegiatan keislaman, baik tingkat regional maupun nasional. Bahkan sebelum diresmikan penggunaannya, area Masjid Hubbul Wathan di Islamic Center (IC) telah menjadi pusat kegiatan penyelenggaraan MTQ Tingkat Nasional ke-26 yang digelar pada tanggal 28 Juli hingga 7 Agustus 2016. Pada bulan ramadhan 1438 H/2017 M, Islamic Center (IC) menjadi pusat kegiatan "Pesona Khazanah Ramadan 2017" yang dilaksanakan selama sebulan penuh, 25 Mei - 26 Juni 2017. Di antara kegiatannya yaitu pelaksanaan shalat tarawih bersama Imam Besar yang didatangkan dari beberapa negara di Timur Tengah, yaitu Prof Dr Syeikh Khalid Barakat dari Lebanon, Syeikh Ezzat El Syarif dari Mesir, Syeikh Mouad Douaik dari Maroko, dan Syeikh Ahmad Jalal Abdullah Yahya dari Yordania. Selain itu juga diisi dengan kegiatan di bidang perekonomian dan kebudyaan Islami, yaitu pameran dan bazaar buku, kuliner halal, pameran busana dan pernak-pernik busana muslimah, pameran foto, handycraft, pameran seni budaya Islam, serta pameran tour dan travel.

Berbagai kegiatan itu telah menempatkan Islamic Center (IC) sebagai icon baru Islam di NTB, khususnya di Kota Mataram. Lokasinya yang strategis, berada di perempatan jalan protokol, yaitu Jalan Langko dan Jalan Udayana, telah mampu menandingi 
keberadaan simbol-simbol agama lain, khususnya Hindu yang banyak mewarnai pemandangan Kota Mataram. Fenomena di atas menunjukkan bahwa keberadaan Islamic Center (IC) dapat menjadi simbol yang menegaskan identitas Islam NTB, khususnya Kota Mataram. Konstruksi identitas Islam itu terjadi melalui berbagai kegiatan keagamaan, baik ritual maupun seremonial yang berlangsung di dalamnya. Selain juga melalui berbagai kegiatan sosial keagamaan yang berlangsung, khususnya di area Masjid Hubbul Wathan yang menjadi icon dari Islamic Center (IC).

Fenomena di atas dapat dipandang sebagai bagian dari bentuk penguatan identitas Islam Waktu Lima pada masyarakat muslim Sasak di Lombok. Islam Waktu Lima adalah Islam yang merujuk kepada ajaran syari'ah secara lebih ketat sebagaimana yang dikemukakan dalam al-Qur'an dan hadis. Sebutan itu juga untuk membedakan dengan Islam Wetu Telu yang bercorak sinkretis dengan unsur filosofi lokal dan praktik ajaran Hindu. Keberadaan komunitas Wetu Telu yang minoritas itu, dalam kajian-kajian tentang Islam Sasak, keberadaannya lebih popular dibandingkan keberadaan Islam mainstream.

Apabila mencermati sejarah perkembangan keagamaan di Lombok, kontestasi identitas agama dalam sejarah masyarakat Lombok telah berlangsung dalam sejarah yang panjang. Sebagaimana dikemukakan oleh Leeman ${ }^{2}$ bahwa identitas masyarakat Lombok sebelum Islam adalah Hindu-Budhisme. Identitas itu dibentuk melalui penetrasi kerajaan Hindu-Majapahit ke tengah orang Sasak pulau Lombok pada abad VII. Dalam Babad Lombok, sebagaimana diuraikan dalam Depdikbud NTB ${ }^{3}$, setelah berhasil mengalahkan kerajaan-kerajaan asli Sasak pengaruh Hindu-Budhisme melahirkan

${ }^{1}$ Konsep tentang Islam Waktu Lima dikemukan oleh Budiwanti untuk membedakan dengan penganut Islam Wetu Telu pada sebagian masyarakat Sasak di Lombok. Selengkapnya lihat Erni Budiwanti, Islam Sasak Wetu Telu Versus Waktu Lima, terj. Noor Cholis dan Hairus Salim S, (Yogyakarta: LKiS, 2000), hlm. 1.

2 Albert Leeman, Internal and External Factors of Socio-Cultural and SocioEconomic Dynamics in Lombok (Zurich: Universitat Zurich, 1989).

${ }^{3}$ Depdikbud NTB. Monografi Daerah Nusa Tenggara Barat Jilid I (Jakarta: Proyek Pengembangan Media Kebudayaan Dirjen Kebudayaan Depdikbud, 1077), hlm. 23-30. 
kerajaan Selaparang Hindu. Masa kejayaannya berakhir ketika Gajah Mada berhasil menaklukkannya melalui sebuah ekspedisi di tahun 1344. Ekspedisi itu tidak hanya mencaplok Selaparang, tapi juga kerajaan Perigi, Dompu, dan Bima. Kehancuran kerajaan Selaparang Hindu itu segera memotivasi bermunculannya kerajaankerajaan di Lombok, seperti kerajaan Mumbul, kerajaan Sasak, kerajaan Kedaro, dan kerajaan Langko.

Pembentukan identitas Islam berlangsung seiring dengan masuknya Islam di Lombok. Sebagaimana dituturkan dalam Babad Lombok, Islam diyakini sudah mulai masuk ke Lombok pada abad XIII dibawa oleh Sunan Prapen dari Gresik Jawa Timur yang masuk dari arah barat laut Lombok. ${ }^{4}$ Aroma sufisme/mistisisme Jawa yang terdapat dalam Islam yang dibawa para muballigh segera menarik kesadaran masyarakat Sasak sehingga secara perlahan mampu mengalihkan mereka dari agama semula. Pengaruh Islam semakin menguat, tentu seraya meminggirkan pengaruh Hindu, khususnya di wilayah Lombok bagian Barat. Ketika beberapa abad kemudian orang-orang Makasar Muslim merapat di Lombok Timur pada abad XVI dan berhasil menguasai Selaparang, sebuah kerajaan orang Sasak asli.

Dalam perkembangan selanjutnya, identitas Islam pada masyarakat Sasak di Lombok berkontestasi dengan identitas Hindu yang dibawa para imigran Bali yang mulai berdatangan sejak permulaan abad XVII. Sekitar tahun 1600-an, mereka (terutama dari Karangasem) mulai berdatangan secara bergelombang ke wilayah barat pulau Lombok yang secara geografis terletak jauh dari dua pusat kerajaan Sasak Islam, yaitu kerajaan Pejanggik di

${ }^{4}$ Nama lain yang juga sering disebut adalah Sunan Prapen putra Sunan Giri, salah seorang dari sembilan wali (wali songo), Al-Fadal, Sangupati, dan lainlain. Seorang sejarawan, Cederroth, tidak terlalu percaya dengan sumber dari Babad Lombok karena hanya berdasar mitologi belaka. Lihat Sven Cederroth, The Spell of the Ancestors and the Power of Mekkah: A Sasak Community on Lombok (Goeteborg, Sweeden: ACTA Universitas Gothoburgensis, 1981), hlm. 32. 
pedalaman Lombok Tengah dan kerajaan Selaparang di Kayangan, sebuah kota di pesisir Lombok Timur. ${ }^{5}$

Kedatangan para imigran dari Bali mula-mula bertujuan untuk membuka lahan baru bagi pertanian dan pemukiman. Setelah terbentuk koloni-koloni baru orang-orang Bali di Lombok, menurut Ktut Agung ${ }^{6}$ barulah kemudian mereka beralih untuk penguasaan. Kekuasaan kerajaan Mataram-Hindu yang begitu panjang (1670 - 1820 M) di Lombok, dan Mataram khususnya membawa pengaruh yang sangat besar dalam banyak segi kehidupan kota Mataram. ${ }^{7}$

Seiring dengan menguatnya aktifitas dakwah Islam, pengaruh agama Hindu di kota Mataram semakin melemah. ${ }^{8}$ Dari waktu ke waktu semakin menunjukkan adanya geliat yang mengindikasikan semakin kuatnya Islam menancapkan pengaruhnya dalam berbagai segi kehidupan. Hal ini berbeda dengan pengaruh Hindu, yang semakin "melemah" dan semakin terbatasi ruang lingkup pengaruhnya dari segi wilayah dan dalam bidang tertentu saja. Hal ini dikarenakan terus berlangsungnya kegiatan dakwah Islam, yang berusaha menumbuhkan kesadaran

${ }^{5}$ Fath Zakaria, Mozaik Budaya Orang Mataram (Mataram: Yayasan Sumusmas Al-Hamidy, 1998), hlm. 17.

${ }^{6}$ Anak Agung Ketut Agung, Kupu-kupu Kuning yang Terbang di Selat Lombok: Lintasan Sejarah Kerajaan Karangasem (1661-1950) (Ttp.: Upada Sasatra, 1991), hlm. 93-96.

${ }^{7}$ Jejak-jejak kekuasaan Etnis Bali dan agama Hindu di kota Mataram masih dapat dilihat hingga kini, baik dalam bentuk pranata sosial maupun peribadatan. Dalam bentuk pranata sosial dapat dilihat pada adanya kampung-kampung Bali yang terdapat di beberapa wilayah kecamatan yang ada di Kota Mataram, yaitu kecamatan Mataram, Selaparang, Cakranegara, dan Sandubaya. Keberadaan masyarakat Bali di berbagai wilayah kecamatan tersebut juga didukung dengan adanya organisasi sosial-keagamaan berupa banjar-banjar, seperti banjar rojong, banjar suka duka, dan banjar karya, dan sarana peribadatan Pura yang hingga kini berjumlah 123 buah.

${ }^{8}$ Penyebaran Islam di kota Mataram dipelopori oleh para da'i pedagang dan kyai (tuan guru).Mereka terdiri dari orang Arab, Banjarmasin, dan Melayu Palembang. Mereka inilah yang selanjutnya mendirikan perkampunganperkampungan Arab, Banjar, dan Melayu. Ada juga yang berasal dari Sulawesi, yang kemudian menetap di Pajeruk Ampenan, dan juga dari Sumbawa, yang selanjutnya menetap di Karang Taliwang Cakranegara. Sedangkan para da'i dan kyai yang berasal dari suku Sasak, mereka menetap di beberapa wilayah, seperti Kebon Roweq, Sukaraja, Otak Desa, Gatep, Dasan Agung, Karang Bedil dan Karang Kelok, Taman dan Sekarbela, dan juga di Pagutan. Lihat Zakaria, Mozaik..., hlm. 12. 
kaum muslim Sasak terhadap identitas diri mereka sebagai kaum muslim, khususnya pada komunitas agama (Islam) Wetu Telu. Bahkan keberadaan komuitas yang disebut sebagai penganut Islam Wetu Telu, sebagai wujud paling nyata pengaruh Hindu, sudah tidak ditemukan di Mataram, dan hanya terbatas diwilayah-wilayah tertentu, khususnya di Bayan Lombok Utara. Dengan kata lain bahwa ada proses kesejarahan untuk mengkonstruksi identitas kesasakan yang bercorak Islam. Akibatnya, unsur-unsur lain, seperti agama yang diwarisi dari nenek moyang, juga unsur-unsur yang bercorak Hindu menjadi terpinggirkan.

Pembentukan identitas etnis dan agama itu semakin mendapatkan momentumnya seiring dengan terjadi perubahan kehidupan sosial dan politik yang semakin terbuka pada era reformasi. Untuk menjawab berbagai tuntutan politik dari daerah, kemudian pemerintah pada Era. Reformasi memberlakukan kebijakan otonomi daerah yang memberi kewenangan kepada pemerintah daerah kabupaten/kota untuk mengatur dan mengurus kepentingan masyarakat di wilayah kabupaten/kota masing- masing. ${ }^{9}$

Kebebasan dan keterbukaan pada era reformasi telah memberi ruang yang semakin luas kepada masyarakat Indonesia untuk mengekspresikan kebebasan dalam berbagai aspek kehidupan, termasuk dalam kehidupan beragama dan kehidupan sosial keagamaan. Hal itu mendorong munculnya pembentukan identitas agama pada para penganut agama, tak terkecuali di kalangan kaum muslim.

${ }^{9}$ Untuk mendukung kebijakan itu pemerintah telah menerbitkan beberapa aturan perundangan yaitu: Undang-Undang No. 5 Tahun 1974 tentang Pokok-pokok Pemerintahan Daerah, Undang-Undang No. 22 Tahun 1999 tentang Pemerintahan Daerah, Undang-Undang No. 25 Tahun 1999 tentang Perimbangan Keuangan Antara Pemerintah Pusat dan Daerah, Undang-Undang No. 32 Tahun 2004 tentang Pemerintahan Daerah, Undang-Undang No. 33 Tahun 2004 tentang Perimbangan Keuangan Antara Pemerintah Pusat dan Pemerintahan Daerah, Perpu No. 3 Tahun 2005 tentang Perubahan atas Undang-Undang No. 32 Tahun 2004 tentang Pemerintahan Daerah, dan Undang-Undang No. 12 Tahun 2008 tentang Perubahan Kedua atas Undang-Undang No. 32 Tahun 2004 tentang Pemerintahan Daerah. 
Di berbagai wilayah, di mana penganut Islam menjadi mayoritas, muncul berbagai upaya yang mengarah pada pembentukan, pemeliharaan, dan perlindungan identitas-identitas agama. Wujudnya antara lain dengan mengusung simbol-simbol Islam ke ruang publik. Misalnya dalam bentuk pembangunan pusatpusat kegiatan keislaman, seperti Islamic Center, masjid, lembagalembaga pendidikan Islam, tradisi dan budaya Islam. Dalam banyak kasus, konstruksi identitas Islam juga sangat terkait dengan politik (kekuasaan). Artinya bahwa prosesnya berlangsung melalui campur tangan kekuasaan pemerintah, khususnya pemerintah daerah propinsi, kabupaten, dan kota. Dengan kata lain bahwa para penguasa menjadi aktor-aktor penting yang menggagas dan mendorong proses pembentukan dan penguatan identitas Islam melalui kebijakan-kebijakan yang dicetuskanya.

Fenomena menguatnya identitas etnis dan agama yang menjadi paradoks pelaksanaan desentralisasi juga terjadi pada etnis Sasak di Lombok. Para elit Sasak berupaya menegaskan identitas etnis yang berbasis agama (Islam). Mereka berusaha meneguhkan Islam sebagai identitas Sasak. Hal itu antara lain diwujudkan dengan slogan Lombok sebagai "pulau seribu masjid". Dalam konteks kota Mataram, slogan sebagai "pulau seribu masjid" kurang didukung dengan kenyataan empiris karena di sebagian wilayah kota Mataram, terutama di tempat-tempat yang dianggap strategis (pusat perdagangan Cakranegara dan jalan-jalan protokol) yang nampak adalah bangunan-bangunan tempat ibadah umat Hindu (Pura) dan bangunan lain yang penuh dengan simbol-simbol keHinduan, misalnya patung-patung dewa. Oleh karena itu, identitas Islam pada masyarakat Lombok itu perlu ditegaskan, dipelihara, dan dilindungi. Di antara cara yang dapat dilakukan yaitu dengan membangun simbol-simbol Islam, misalnya dengan membangun Islamic Center yang dirancang sebagai pusat kegiatan peribadatan, pendidikan, ekonomi, dan sosial budaya sebagaimana yang digagas oleh pemerintah provinsi NTB. 
Uraian di atas menggambarkan bahwa konstruksi identitas agama di masyarakat Sasak di Lombok paralel dengan naik turunnya kekuasaan aktornya. Ketika aktor yang berkuasa memiliki komitmen keagamaan yang kuat, maka hal itu akan mewarnai kebijakan-kebijakannya yang mendukung dan memberi ruang tumbuh berkembangnya identitas-identitas keagamaan. Pendekatan yang digunakan dalam penelitian ini adalah kualitatifdeskriptif. Dengan menggunakan pendekatan kualitatif-deskriptif, ${ }^{10}$ tulisan ini berusaha mengkaji bagaimana bentuk-bentuk peran kekuasaan (khususnya era gubernur TGB. Zainul Madjdi atau Tuan Guru Bajang) dalam mengkonstruksi identitas Islam (baru) melalui pembangunan Islamic Center.

\section{B. Islamic Center dan Identitas Baru Islam di Lombok}

Secara historis ide atau gagasan untuk membangun Islamic Center sudah muncul semenjak kepemimpinan tiga gubernur sebelum TGB, yaitu Gubernur Warsito (1988-1993 dan 19931998), Gubernur Harun al-Rasyid (1998-2003), dan Gubernur Gubernur Lalu Serinata (2003-2008). Namun gagasan itu baru terwujud pada masa pemerintahan gubernur TGB. Zainul Majdi (2008-2013 dan 2013-2018). Secara politis, hal itu menunjukkan bahwa membangun Islamic Center belum menjadi kebijakan prioritas pada masa kepemimpinan dua gubernur sebelumnya, sehingga belum ada usaha yang sangat serius untuk mewujudkan gagasan Islamic Center menjadi kenyataan. Pembangunan Islamic Center dapat dipandang sebagai titik kulminasi identitas Islam yang berhasil dikonstruksi pada era pasca reformasi. Hal itu tidak terlepas dari kesempatan berkuasa yang diperoleh umat Islam dalam pentas politik lokal, khususnya terpilihnya TGB Zainul Majdi menjadi gubernur Nusa Tenggara Barat. Power politik dan keagamaan yang dimiliki TGB Zainul Majdi memberi ruang yang 2002), hlm. 51.

${ }^{10}$ Sudarwan Danim, Menjadi Peneliti Kualitatif (Bandung: Pustaka Setia, 
sangat luas baginya untuk mengambil kebijakan yang "berpihak" kepada umat Islam.

Sebagaimana disebutkan dalam laman resmi Pemerintah Provinsi Nusa Tenggara Barat, visi Islamic Center adalah menjadi pusat syiar dan pengembangan peradaban Islam yang bertaraf internasional. Sedangkan misinya adalah pertama, sebagai wadah untuk mewujudkan sumberdaya manusia yang memiliki wawasan keagamaan tinggi dan menguasai ilmu pengetahuan dan teknologi. Kedua, sebagai pusat dakwah dan pengembangan nilai-nilai social budaya serta ekonomi masyarakat yang Islami. Ketiga, sebagai bangunan monumental yang dapat menjadi land mark Nusa Tenggara Barat dan menjadi tujuan wisata religi yang terkenal. ${ }^{11}$

Apabila mencermati visi dan misi Islamic Center di atas, ada satu hal menarik yang terkait dengan konstruksi identitas Islam, yaitu menjadikan Islamic Center sebagai land mark Nusa Tenggara Barat dan tujuan wisata religi. Misi ini tidak terlepas dari keberadaan umat Islam sebagai warga mayoritas Pulau Lombok khususnya dan Nusa Tenggara Barat pada umumnya. Keberadaan Islam sebagai agama yang dipeluk mayoritas umat Islam di Lombok antara laian ditunjukkan dengan banyaknya tradisi-tradisi Islam yang dipraktikkan umat Islam. Selain itu juga ditunjukkan dengan banyaknya jumlah masjid yang ada di wilayah Lombok sehingga dijuluki dengan pulau seribu masjid. Namun, sebutan itu belum cukup menjadikan bangunan masjid yang tersebar di berbagai wilayah Lombok menjadi land mark yang menarik para wisatawan untuk mengunjunginya. Sebaliknya, mereka yang datang ke Lombok dan Nusa Tenggara Barat lebih tertarik untuk mengunjungi keindahan alam pantai dan gunung rinjaninya serta berbagai peninggalan kerajaan Hindu, seperti pura dan taman. Land mark yang berupa taman dan pura itu sekaligus menjadi destinasi wisata religi bagi wisatawan yang beragama Hindu.

Kondisi seperti di atas mendorong Pemerintah Provinsi Nusa Tenggara Barat untuk membangun Islamic Center yang

\footnotetext{
${ }^{11}$ wnwn.ntb.go.id
} 
diharapkan dapat menjadi land mark bagi wilayah Lombok dan Nusa Tenggara Barat serta menjadi tujuan wisata religi bagi wisatawan yang beragama Islam. Dengan kata lain bahwa keberadaan Islamic Center diharapkan dapat memperkokoh identitas Islam yang telah ada sebelumnya.

Apabila dipandang dari perspektif teori identitas yang dikemukakan Castels ${ }^{12}$, maka apa yang ditampilkan oleh pemerintahan TGB. Zainul Majdi melalui Islamic Center merupakan sebuah upaya mengkonstruksi identitas project, yaitu Islam yang kosmopolit. Hal itu sekaligus untuk menghapus stigmatisasi Islam Sasak yang pinggiran, sinkretis, dan tradisional yang diproduksi oleh kekuasaan (Hindu) sebelumnya. Hegemoni kekuasaan Hindu di Lombok meninggalkan jejak dalam banyak aspek pada kehidupan masyarakat Lombok, terutama di Mataram. Jejak-jejak kekuasaan Etnis Bali dan agama Hindu di kota Mataram masih dapat dilihat hingga kini, baik dalam bentuk pranata sosial maupun peribadatan. Dalam bentuk pranata sosial dapat dilihat pada adanya kampung-kampung Bali yang terdapat di beberapa kecamatan. Di antara enam kecamatan yang ada di kota Mataram, etnis Bali banyak tinggal di wilayah kecamatan Mataram, Selaparang, Cakranegara, dan Sandubaya. Menurut data kependudukan dari BPS Kota Mataram tahun 2016 jumlah penduduk etnis Bali di empat kecamatan tersebut mencapai 53.863 jiwa atau sekitar 11,5\% dari total penduduk kota Mataram yang berjumlah 481.907 jiwa. Keberadaan masyarakat Bali di berbagai wilayah kecamatan tersebut juga didukung dengan adanya organisasi sosial-keagamaan berupa banjar-banjar, seperti banjar rojong, banjar suka duka, dan banjar karya. Untuk sarana peribadatan, di wilayah empat kecamatan tersebut tersedia 183 buah Pura. ${ }^{13}$

Upaya untuk mengkonstruksi identitas baru Islam pada masyarakat muslim Lombok itu penting dilakukan karena

${ }^{12}$ Manuel Castells, The Power of Identity, The Information Age: Economy, Society, and Culture (USA: Blackwell Publishers, 1997), hlm. 5.

${ }^{13}$ BPS Kota Mataram. Mataram dalam Angka (Mataram: BPS Kota Mataram, 2017). 
keberadaan simbol-simbol yang ada dianggap belum legitimate dalam meneguhkan keislaman masyarakat Lombok, seperti keberadaan ribuan masjid yang tersebar di pulau Lombok. Untuk Kota Mataram yang menjadi pusat pemerintahan (Provinsi NTB dan Kota Mataram) dan pusat perekonomian, identitas Islamnya tidak begitu nampak. Bahkan yang lebih menonjol adalah identitas Hindu diwariskan oleh Kerajaan Hindu Karangasem Mataram. Oleh karena itu perlu dikonstruksi identitas baru yang lebih legitimate dan kosmopolit sesuai dengan perkembangan masyarakat Lombok dan NTB. Wujudnya adalah Islamic Center yang di dalamnya menyatukan nilai-nilai Islam, IPTEK, dan ekonomi.

Kepentingan untuk menghadirkan wajah baru Islam yang kosmopolit, sampai sejah ini belum didukung realitas faktual keberadaan Islamic Center. Apabila mencermati bangunan Islamic Center, maka nampak bahwa bagunan masjid menjadi bagian yang paling dominan. Dibandingkan dengan bangunan-bangunan lain yang sudah dan yang akan dibangun, maka bangunan masjid memiliki area yang paling luas, yaitu mencapai $36.538 \mathrm{~m}^{2}$. Hal ini menegaskan bahwa keberadaan Islamic Center menjadi bagian dari upaya meneguhkan identitas Islam bagi Kota Mataram. Ketika orang menyebut Islamic Center, maka secara otomatis yang dibayangkan adalah keberadaan Masjid Hubbul Wathan yang megah. Begitu juga ketika orang menyaksikan area Islamic Center dari kejauhan, maka yang Nampak adalah menara masjid Hubbul Wathan yang menjulang ke angkasa. Begitu juga ketika orang melewati Jalan Udayana ataupun Jalan Langko, maka ketakjuban mereka bukan karena melihat bangunan gedung pendidikan atau bangunan lain yang ada di area Islamic Center, tetapi bangunan Masjid Hubbul Wathan yang menakjubkan. 


\section{Bentuk Peran Kekuasaan dalam Pembangunan Islamic Center}

\section{Peran dalam penyediaan anggaran dalam APBD Provinsi NTB}

Sebuah pemerintahan senantiasa berusaha memenuhi kebutuhan-kebutuhan hidup masyarakat, termasuk kebutuhan dalam bidang sosial keagamaan. Wujudnya antara lain dalam bentuk penyiapan sarana prasarana yang menjadi wadah bagi pemenuhan dan pengembangan kebutuhan spritual dan sosial-keagamaan warganya, khususnya mereka yang beragama Islam.

Dalam konteks Nusa Tenggara Barat (NTB), wujudnya antara lain adalah dibangunnya Islamic Center yang diperuntukkan bagi pemenuhan kebutuhan spiritual, sosial, dan ekonomi umat Islam. Dalam mewujudkan Islamic Center itu peran pemerintah provinsi Nusa Tenggara Barat sangat besar. Peran itu sudah mulai diwujudkan semenjak masa pemerintahan gubernur L. Serinata yang memerintah mulai 31 Agustus 2003-1 September 2008. Pada masa pemerintahan gubernur pertama dari suku Sasak itu telah dibentuk kepanitiaan yang diberi tugas untuk menindak lanjuti gagasan tentang pembangunan Islamic Center.

Sebagaimana diakui oleh gubernur TGB. Zainul Madjdi bahwa pada awalnya gagasan untuk membangun Islamic Center di lokasi bekas KONI kurang mendapat respons positif dari sebagian anggota DPRD NTB. Salah seorang anggota DPRD NTB juga menyoroti soal mekanisme pembangunan Islamic Center yang diserahkan langsung sepenuhnya kepada Dinas PU. Menurutnya perlu dibentuk kepanitiaan khusus yang bertanggung jawab atas pembangunan Islamic Center. Namun pada akhirnya suara-suara anggota DPRD tersebut tidak mampu menghalangi terwujudnya Islamic Center yang sudah lama dinantikan oleh umat Islam NTB. Sebagaimana dinyatakan oleh gubernur TGB. Zainul Madjdi pada saat upacara peletakan batu pertama dan pembukaan selubung papan nama "Islamic Center" bahwa "kita berencana namun Allah 
SWT yang akan menentukan, dan jika Allah berkehendak maka 'Islamic Center' ini pasti jadi'. ${ }^{14}$

Ungkapan di atas menggambarkan adanya penggunaan power pengetahuan keagamaan (teologis) yang dimiliki gubernur TGB. Zainul Madjdi sebagai Ulama atau Tuan Guru untuk menumbuhkan dan memperkokoh keyakinan publik akan keberhasilan pembangunan Islamic Center. Mengapa diyakini berhasil, karena akan ada campur tangan Allah di dalamnya. Manusia memang hanya merencanakan, namun ketika yang direncanakan itu adalah hal yang baik, lebih-lebih hal yang terkait dengan ibadah, yaitu membangun pusat Islam, termasuk di dalamnya rumah Allah (masjid), maka Allah akan mendukungnnya. Keyakinan seperti itu penting ditegaskan untuk menjawab pihak-pihak yang merasa kurang yakin akan keberhasilan pembangunan Islamic Center.

Pandangan yang dikemukakan Gubernur TGB. Zainul Madjdi di atas mengandung nilai ideologis. Sebagaimana dikemukakan Barker, ideologi dimaknai sebagai pandangan dunia kelompok sosial yang menjustifikasi tindakan mereka dan yang setara dengan kebenaran. ${ }^{15}$ Dengan kata lain bahwa pandanganpandangan agama yang dikemukakan oleh TGB. merupakan bagian dari cara untuk menjustifikasi kebenaran kebijakannya untuk membangun Islamic Center. Argumentasinya adalah bahwa membangun Islamic Center, yang di dalamnya terdapat bangunan masjid, adalah sebuah kebijakan yang baik karena merupakan bagian dari ibadah. Oleh karena itu Allah pasti akan meridhoinya dengan memberikan jalan yang memudahkan untuk dapat diwujudkannya kebijakan tersebut.

Dalam praktik di atas, klaim ideologis ditanamkan dengan rasional melalui kepemimpinan intelektual, yaitu sebagai

${ }^{14}$ https://mataram.antaranews.com/berita/9109/pembangunan-islamiccenter-ntb-dimulai

${ }^{15}$ Barker Chris Barker, Cultural Studies Teori dan Praktik. (Yogyakarta: Kreasi Wacana, 2004), hlm. 66. 
intelektual agama atau ulama. ${ }^{16}$ Kepemimpinan intelektual dan politik kemudian digunakan untuk menggiring kesadaran masyarakat (kelompok lain) dalam arah yang diinginkan. ${ }^{17}$ Oleh karena itu kuasa/pengetahuan atau power/knowledge biasanya ada pada kelompok elit, misalnya elit agama dan elit politik. Para elit agama membangun kuasa melalui otoritasnya dalam memproduksi pengetahuan agama sehingga memperkokoh kemampuannya untuk mempengaruhi masyarakat (jamaahnya). Sedangkan elit politik memproduksi pengetahuan melalui peraturan dan undang-undang yang digunakan untuk mempengaruhi masyarakat pendukungnya. Dalam konteks gubernur TGB, yang bersangkutan adalah elit agama dan sekaligus elit politik.

Secara empiris, untuk menunjukkan kesungguhannya dalam mewujudkan Islamic Center gubernur TGB. Zaenul Madjdi mewujudkannya dalam berbagai kebijakan politik. Ada beberapa kebijakan yang diambil oleh gubernur TGB. Zainul Madjdi dalam mendukung pembangunan Islamic Center, yaitu menyerahkan sepenuhnya pembangunannya kepada Dinas Pekerjaan Umum Provinsi Nusa Tenggara Barat, mengalokasikan dana dalam APBD NTB, memanfaatkan dana CSR dari PT Newmont Nusa Tenggara, dan menghimpun dana masyarakat, khususnya melalui sumbangan wajib pegawai negeri sipil di NTB.

Pilihan kebijakan gubernur TGB. Zainul Madjdi untuk menyerahkan sepenuhnya pembangunan Islamic Center kepada Dinas Pekerjaan Umum membawa konsekwensi pada tidak diperlukan adanya kepanitiaan khusus dalam pembangunannya sehingga tidak ada pihak di luar pemerintah provinsi yang terlibat secara intensif. Kebijakan seperti itu sekaligus juga menggambarkan adanya keinginan besar gubernur TGB. Zainul Madjdi menunjukkan perannya yang sentral dalam pembangunan Islamic Center. Besarnya peran gubernur pada

${ }^{16}$ John B. Thompson, Kritik Ideologi Global Teori Sosial Kritis tentang Relasi dan Komunikasi Massa (Yogyakarta: IRCISOD, 2006), hlm. 60.

${ }^{17}$ Bagus Takwim, Akar-Akar Ideologi Pengantar Kajian Konsep Ideologi dari Plato hingga Bourdieu (Yogyakarta: JALASUTRA, 2009), hlm. 73. 
satu sisi dan kurangnya keterlibatan unsur pemerintahan lainnya di tingkat provinsi maupun kota/kabupaten dalam pembangunan Islamic Center antara lain dikemukakan informan dari kalangan Kementerian Agama Provinsi Nusa Tenggara Barat maupun Kota Mataram. Ketika ditanyakan tentang bentuk keterlibatannya dalam pembangunan Islamic Center seorang informan dari BIMAS Islam Kemenag Kota Mataram menyatakan bahwa "ide utamanya ya dari pemerintah provinsi. Dalam hal ini ide dari bapak gubernur TGB. Jadi bisa dikatakan ini gawenya pemda mulai dari perecanaan sampai menejmen pengelolaannya, bahkan sekarang sudah menjadi UPTD tersendiri dibawah Pemerintah Provinsi Nusa Tenggara Barat". ${ }^{18}$

Ungkapan senada juga dikemukakan informan lainnya dari BIMAS Islam Kemenag Provinsi Nusa Tenggara Barat. Ketka ditanyakan kepadanya tentang pembangun Islamic Center ia menyatakan bahwa "penggagasnya adalah pemerintah provinsi NTB. Secara struktural tidak ada keterlibatan Kementerian Agama dalam pembangunan. Keterlibatannya hanyalah pada bentuk sumbangan dana penarikan infaq dan sadaqah sebagaimana yang juga dilakukan di Dinas-Dinas yang ada di Provinsi maupun Kabupaten dan Kota di Nusa Tenggara Barat". ${ }^{19}$

Selama masa pemerintahan TGB. Zainul Madjdi, pemerintah provinsi NTB telah mengucurkan dana untuk pembangunan Islamic Center sebesar lebih 500 milyar. Dalam APBD tahun 2009 dialokasikan sejumlah 300 juta rupiah, dan dalam APBD 2010 dialokasikan sebanyak 15 milyar rupiah. Dalam APBD NTB tahun anggaran 2011 dialokasikan 64 milyar, APBD tahun 2012 sejumlah 123,2 milyar, APBD tahun 2013 sejumlah 136,4 milyar, APBD tahun 2014 sejumlah 149,6 milyar. $^{20}$

Sedangkan untuk mendorong percepatan realisasi pembangunan berbagai fasilitas di Islamic Center, pada tanggal 16 Juni 2013 di Ruang Rapat Utama kantor Gubernur NTB,

\footnotetext{
${ }^{18}$ Wawancara, tanggal 3 Agustus 2018.

${ }^{19}$ Wawancara, tanggal 3 Agustus 2018.

${ }^{20}$ Buku Manual Pembangunan Islamic Center Nusa Tenggara Barat, hlm. 18.
} 
Gubernur TGB. M. Zainul Madjdi telah menandatangani Memorandum of Understanding (MOU) dengan tiga investor, yaitu PT. Lombok Plaza, PT. Al-Hamra Internasional, PT. Varindo Lombok Inti. Penandatanganan MoU tersebut masing-masing untuk pembangunan NTB Convention Centre (NCC), Pembangunan Hotel Syariah di kompleks Islamic Centre dan Pembangunan Rumah Kantor (Rukan). Sesuai dengan hasil beauty contest yang dilakukan tim terpadu dari pemprov NTB, pekerjaan pembangunan NTB Convention Centre (NCC) dimenangkan oleh PT. Lombok Plaza dengan rencana investasi Rp 360 miliar dan kontribusi Rp 50 miliar. Untuk pembangunan Hotel Syariah di Kompleks Islamic Center dimenangkan oleh PT. Al-Hamra Internasional dengan investasi $\mathrm{Rp}$ 75.424.500.000 dengan kontribusi Rp 74.703.041.498. Sementara untuk pekerjaan pembangunan rumah kantor (rukan), pemenang pertama adalah PT. Varindo Lombok Inti. Varindo berencana berinvestasi sekitar Rp 11.269.187.500 dengan kontribusi Rp 1.125.000.000. ${ }^{21}$

Apabila dicermati perincian penggunaan anggaran pembangunan Islamic Center di atas, nampak bahwa pembangunan Masjid Hubbul Wathan menyerap anggaran paling besar, yaitu lebih dari 421 milyar rupiah. Apabila total keseluruhan anggaran pembangunan Islamic Center, sebagaimana dikemukakan Kepala Dinas PUPR NTB, Wedha Magma Ardhi, sebesar 600 milyar rupiah $^{22}$, maka anggaran untuk pembangunan Masjid Hubbul Wathan menyerap $70 \%$ lebih dari total anggaran pembangunan Islamic Center.

Terhadap kebijakan gubernur TGB. Zainul Majdi yang mengalokasikan APBD NTB untuk pembanguan Islamic Center hampir tidak ada kritikan dan reaksi ketidaksetujuan yang dilontarkan oleh masyarakat. Termasuk juga terhadap serapan anggaran pembangunan Islamic Center yang 70\%-nya diperuntukan untuk pembangunan Masjid Hubbul Wathan. Secara

\footnotetext{
${ }^{21}$ www.ntb.go.id

${ }^{22}$ https://www.talikanews.com/islamic-center-telan-biaya-rp-600-miliar/
} 
politis, kebijakan TGB. tersebut mencerminkan keperpihakannya kepada kaum muslim yang merupakan mayoritas penduduk NTB. Ada kritikan yang dilontarkan politisi PDIP, yaitu Rahmat Hidayat yang menyuarakan kritikannya atas penggunaan APBD NTB untuk pembangunan Masjid Hubbul Wathan karena dianggap tidak sesuai rencana awal pembangunan Islamic Center yang akan dijadikan sebagai pusat pendidikan dan Ilmu Pengetahuan dan Teknologi. Penggunaan anggaran tersebut menurutnya mubadzir karena tidak mendatangkan keuntungan bagi masyarakat NTB secara keseluruhan. Apalagi ada kebijakan juga untuk sumbangan dari para PNS yang dipotong langsung dari gaji yang mereka terima tiap bulan. ${ }^{23}$ Namun, kritikan yang muncul itu menjadi suara sayubsayub yang segera hilang ditelan keriuhan euforia kebanggaan umat Islam atas keberadaan land mark baru Islam bagi Kota Mataram dan Nusa Tenggara Barat.

Munculnya kritikan tersebut di atas tidak terlepas dari besarnya serapan anggaran pembangunan Islamic Center untuk pembangunan Masjid Hubbul Wathan mengisyaratkan bahwa pembangunan Islamic Center hakekatnya adalah projek pembangunan masjid. Hal itu juga didukung dengan kenyataan empiris bahwa sampai pertengahan tahun 2018 fasilitas yang mendukung kegiatan ekonomi di Islamic Center, yaitu Hotel Syari'ah dan Rumah Kantor (Rukan) belum terwujud. Sehingga ketertarikan pengunjung untuk datang ke Islamic Center adalah karena keinginan untuk menyaksikan kemegahan Masjid Hubbul Wathan dan keinginan untuk beribadah di tempat yang lebih nyaman yang mendukung tercapainya ketenangan dan kekhusu'an. Dengan demikian, sampai saat ini misi yang menonjol pada Islamic Center adalah baru sebatas misi dakwah Islam dalam pengertian mendukung pelaksanaan ritual-peribadatan bagi umat Islam. Sementara misi untuk pembinaan sumber daya manusia berwawasan keislaman yang menguasai iptek, dan menumbuhkan bermasalah/

${ }^{23}$ http://dutaselaparang.com/politik/pdi-p-sebut-anggaran-ic-ntb- 
etos wirausaha yang berbasiskan nilai-nilai Islam masih belum nampak. Oleh karena itu arti penting Islamic Center bagi masyarakat Nusa Tenggara Barat khususnya, baru sebatas menjadi pusat ibadah dan pusat wisata religi. Sedangkan arti penting sebagai pusat pendidikan terpadu, pusat bisnis dan pengembangan ekonomi umat, pusat kajian dan pengembangan pemikiran Islam, dan pusat pengembangan kebudayaan dan iptek masih belum nampak.

Pembangunan Islamic Center, di mana Masjid Hubbul Wathan menjadi bagian pentingnya, nampaknya juga menjadi jawaban terhadap keluhan-keluhan yang disuarakan sebagian masyarakat muslim tentang keberadaan kota Mataram yang belum mencerminkan bahwa penduduknya mayoritas muslim. Belum ada simbol-simbol Islam yang menjadi land mark kota Mataram. Sebaliknya, yang banyak adalah simbol-simbol yang mencerminkan keberadaan Agama Hindu. Sepanjang jalan protokol dari arah Ampenan-Cakranegara (Jalan Langko, Jalan Pejanggik) dan arah Cakranegara-Ampenan (Jalan Catur Warga dan Jalan Pendidikan) tidak ada bangunan yang mencerminkan land mark Islam, khususnya masjid. Keberadaan Masjid Raya At-Taqwa sudah "tenggelam" di antara gedung-gedung yang ada di sekitarnya. Oleh karena itu, keberadaan Islamic Center dengan Masjid Hubbul Wathan-nya dianggap mampu meneguhkan keberadaan Kota Mataram sebagai wilayah dengan penduduk mayoritas muslim.

Ada juga suara yang muncul dari kelompok minoritas tentang kurangnya keberpihakan pemerintah provinsi NTB kepada mereka. Salah seorang informan dari Sekolah Tinggi Agama Hindu Negeri Gde Pudja, mengeluhkan lokasi yang digunakan pembangunan Islamic Center. Menurutnya, lokasi pembangunannya seharusnya tidak di kompleks KONI karena di situ merupakan tempat yang ditabukan oleh umat Hindu karena dulu digunakan sebagai tempat pembakaran mayat warga Hindu Bali di masa lampau. Oleh karena itu secara etika seharusnya kita saling menghormati keyakinan antar penganut agama dengan cara menghargai apa yang dianggap suci oleh penganut agama lain. Ia 
juga menunjukkan kurangnya keberpihakan pemerintah provinsi kepada kelompok minoritas, terutama dalam masalah pendidikan agama Hindu. Menurutnya jumlah berbagai lembaga pendidikan Islam yang memproduksi para ustadz, da'i, dan guru agama sangat tidak sebanding dengan yang ada di umat Hindu. Namun ketika pihaknya mengajukan kebutuhan pengadaan guru agama Hindu, tidak ada respons yang positif dari pemerintah. ${ }^{24}$

\section{Peran dalam penggalangan dana masyarakat}

Selain menyiapkan anggaran pembangunan Islamic Center melalui APBD NTB, pemerintah provinsi NTB juga berusaha menggalang dana dari masyarakat, khususnya dari para pegawai negeri sipil. Kebijakan ini dilakukan melalui "kerjasama" dengan Korps Pegawai Republik Indonesia (KORPRI) NTB. Meskipun dilakukan oleh KORPRI, namun karena lembaga PNS tersebut sudah menjadi satuan kerja perangkat daerah, pungutan tersebut berarti dilakukan oleh pemerintah. Surat edaran Nomor : 068/ K-5/Korpri Tanggal 31 Mei 2010 perihal Himbauan Partisipasi Pembangunan Islamic Center yang dikeluarkan oleh pengurus Korpri NTB yang ditandatangani oleh para ketuanya, Muhammad Nur, Djoharuddin dan M Hirsan Ma'ruf, menurut Ruslan bukan himbauan, "Tetapi instruksi dari atasan ke bawahan. Banyak yang mengeluhkannya."

Dalam surat edaran tersebut disebutkan bahwa untuk pembangunan Islamic Center yang memerlukan biaya sekitar Rp 500-an miliar tersebut, pegawai negeri sipil dikenakan pungutan sesuai golongan dan eselon jabatannya. Mulai dari pejabat eselon I sebesar Rp 200 ribu, II-Rp 100 ribu, III-Rp 75 ribu, IV Rp 50 ribu. Pegawai staf dikenai pungutan berbeda, yaitu golongan pangkat I-Rp 5 ribu, II-Rp 10 ribu, III-Rp 25 ribu, IV-Rp 30 ribu. Sedangkan pegawai fungsional golongan IV-Rp 40 ribu, III-Rp 30 ribu, II-20 ribu.

\footnotetext{
${ }^{24}$ Wawancara, 15 Agustus 2015.
} 
Meskipun pada awalnya sempat menjadi polemik karena oleh salah seorang anggota DPRD NTB menganggap bahwa penggalangan dana dari PNS tersebut belum memiliki payung hukum dalam bentuk Perda. ${ }^{25}$ Namun polemik itu hilang begitu saja, dan pungutan sumbangan PNS untuk pembangunan Islamic Center terus berjalan. Hasilnya, di tahun 2010 panitia penggalangan dana untuk pembangunan Islamic Center juga berhasil mengumpulkan sumbangan dana dari masyarakat, khususnya dari pegawai negeri sipil sejumlah 3,5 milyar lebih. Sedangkan dari dana tanggungjawab sosial (CSR) PT Newmont Nusa Tenggara (PTNNT) berjumlah 32,8 milyar yang diperuntukan untuk pembangunan minaret atau menara 99.

Dukungan dana dari pemerintah provinsi NTB dan Gubernur TGB. Zainul Majdi bukan hanya pada pembangunan Islamic Center, tetapi juga pada beberapa kegiatan ritual dan sosial keagamaan. Misalnya pembiayaan untuk mendatangkan ulamaulama dari Timur Tengah, sepenuhnya ditanggung pemerintah provinsi NTB. Begitu juga ketika mendatangkan ulama atau ustadz Indonesia yang sedang populer di media, pembiayaannya juga ditanggung pemerintah provinsi NTB. Mengenai pemberian honor dan besarannya, pengurus Masjid Hubbul Wathan Islamic Cenrer menyatakan "... sudah pasti karena mereka diundang secara resmi oleh pemprov. Besaran honornya sudah ada ketentuan perdanya. Mereka dihitung honornya berdasarkan dollar dengan kisaran antara 6000 - 7000 US dollar. Belum lagi bisyarah dari pribadi TGB pasti memberikan dari kantong peribadi beliau sendiri, karena beliau orang yang memahami cara menghargai ilmu dan ulama. ${ }^{26}$

\section{Peran dalam manajemen pengelolaan}

Selain dalam bentuk dukungan anggaran dalam APBD Provinsi NTB, gubernur juga menunjukkan perannya dalam pengelolaan Islamic Center. Seluruh manajemen pengelolaan

${ }^{25}$ https:// nasional.tempo.co/read/272706/pungutan-dana-islamiccenter-ntb-dipertanyakan $/$ full\&view $={ }_{\mathrm{ok}}$

${ }^{26}$ Wawancara, tanggal 25 September 2018. 
Islamic Center berada di bawah kontrol gubernur Nusa Tenggara barat, TGH. Zainul Majdi. Sebagaimana dikemukakan oleh seorang informan bahwa pengelolaan Islamic Center sepenuhnya berada di tangan Gubernur TGH. Zainul Majdi sebagai penguasa tertinggi pemerintah provinsi Nusa Tenggara Barat. Pengelolaan Islamic Center dilakukan oleh tiga pihak, yaitu Badan Pengelola Keuangan dan Aset Daerah (BPKAD), Pengurus Umum, dan Pengurus Khusus. Semua pengelola itu ditunjuk secara resmi oleh gubernur melaui pembentukan Tim Khusus, dan selanjutnya dituangkan dalam Surat Keputusan Gubernur. ${ }^{27}$

Penggelontoran dana APBD yang besar untuk pembangunan Islamic Center berkonsekwensi pada penguasaanya sebagai aset milik Pemerintah Provinsi NTB. Oleh karena itu pemerintah provinsi memiliki kewajiban dan tanggung jawab untuk mengelolanya dengan sebaik-baiknya sebagai aset daerah. BPKAD sebagai Badan yang memiliki kewenangan mengelola Islamic Center sebagai aset daerah yang diharapkan memberikan nilai tambah bagi pemerintah provinsi NTB, khususnya dari segi ekonomi. Untuk dapat menjalankan tugas dan tanggung jawab di atas, selanjutnya pemerintah provinsi NTB juga membentuk Unit Pelaksana Teknis (UPT) yang khusus mengelola Islamic Center, yaitu UPT Islamic Center yang secara administratif berada di bawah Badan Pengelola Keuangan dan Aset Daerah (BPKAD). Struktur organisasinya terdiri dari Kepala Uinit Islamic Center, Kasubbag. Tata Usaha, Kasi. Pemeliharaan Sarana dan Prasarana, Kasi. Pemanfaatan, Pengembangan Usaha dan Bisnis.

Sebagai Unit Pelaksana Teknis yang ada dalam BPKAD, UPT Islamic Center mempunyai tugas dan tanggung jawab mendukung pelaksanaan tugas BPKAD dalam memberikan dukungan atas penyelenggaraan pemerintahan daerah di bidang pengelolaan keuangan dan aset. Dalam tahun 2018 ini, dengan terbitnya Peraturan Daerah (PERDA) Nomor 5 Tahun 2018 tentang Retribusi Daerah, maka UPT Islamic Center telah

\footnotetext{
${ }^{27}$ Wawancara, 25 September 2018.
} 
mempunyai payung hukum yang menjadi landasan untuk menarik retribusi kepada pihak-pihak yang memanfaatkan berbagai fasilitas yang ada di Islamic Center. Sebagaimana dikemukakan oleh Kepala BPKAD Provinsi NTB menargetkan pendapatan dari retribusi Islamic Center pada tahun 2018 ini sebesar 2 milyar rupiah. ${ }^{28}$

Selain UPT Islamic Center yang mengkhususkan pengelolaan aset daerah yang diharapkan menambah pendapatan asli daerah (PAD), juga ada pengelola kegiatan Islamic Center, yaitu pengurus Islamic Center. Pengurus ini terdiri dari pengurus umum dan pengurus harian. Pengurus umum bertanggung jawab atas segala kegiatan yang ada di Islamic Center, termasuk pelaksanaan event penting seperti khazanah ramadhan, kegiatan kegiatan yang berskala nasioal dan lain-lain. Sedangkan pengurus harian bertanggung jawab dalam pelaksanaan kegiatan harian dalam memakmurkan masjid seperti, penetapan imam, khatib, penceramah, dan pengisi kajian harian (sebagai ta'mir). ${ }^{29}$

Untuk memberdayakan keberadaan Islamic Center, gubernur TGB. Zainul Madjdi juga ditunjukkan dalam bentuk Peraturan Gubernur (Pergub). Kalau pada pergub sebelumnya disebutkan bahwa BAZDA merupakan satu-satunya Unit Pengelola Zakat (UPZ). Dalam Peraturan Gubernur (Pergub) NTB Nomor 15 Tahun 2016 tentang Pedoman Teknis Penyelenggaraan dan Pengelolaan Zakat, Infak, dan Sedekah, dalam Bab IV Pasal 33 Ayat 2 disebutkan bahwa salah satu lembaga yang berwenang menjadi Unit Pengumpul Zakat (UPZ) yaitu Masjid Raya/Islamic Center. Secara tidak langsung, terbitnya peraturan gubernur di atas menunjukkan semangatnya untuk memberdayakan Islamic Center dengan memberi kewenangan untuk mengelola dan menyalurkan zakat, infak, dan sedekah dari masyarakat.

${ }^{28}$ http://www.gardaasakota.com/2018/06/pad-islamic-center-hubbulwathan-tahun.html

${ }^{29}$ Wawancara, 25 September 2018. 


\section{Peran dalam sosialisasi dan publikasi}

Ketika sebuah identitas telah terwujud, ia dipelihara, dimodifikasi, atau dikonstruksi ulang melalui hubungan-hubungan sosial. Begitu juga dengan Islamic Center sebagai identitas Islam NTB, perlu terus dipelihara dan diteguhkan keberadaanya. Prosesnya dilakukan melalui internalisasi, yaitu tahapan di mana berlangsung proses yang bertujuan untuk memperkokoh identitas kelompok. Seorang individu tidak dilahirkan sebagai anggota masyarakat, tetapi memiliki kecenderungan ke arah sosialitas, maka sebelum individu menjadi anggota masyarakat maka ia perlu mendapatkan bahan-bahan yang akan menjadi acuan untuk mengenal diri dan sesamanya, dan pemahaman mengenai dunia sebagai sesuatu yang maknawi dari kenyataan sosial. Identitas sosial pada individu secara terus menerus direproduksi sebagaimana yang dikehendaki oleh perubahan-perubahan yang berlangsung dalam masyarakat. Melalui proses internalisasi nilai-nilai yang berkembang dalam masyarakat, maka individu dituntut untuk terus menerus melakukan pendefinisian identitas sosialnya sehingga keanggotannya dalam komunitas sosial dapat terpelihara. ${ }^{30}$

Selain menjadi penguasa (gubernur NTB), TGB. Zainul Madjdi juga menempati posisi penting dalam wilayah ketuan guruan (keulamaan). TGB. Zainul Madjdi adalah seorang doktor tafsir al-Qur'an lulusan Universitas al-Azhar Mesir. Kehadiran beliau yang cukup lama (lebih 6 tahun) di Timur Tengah menghasilkan jejaring intelektual dengan para ulama di negaranegara di Timur Tengah. Keberadaannya sebagai elit politik dan elit agama memudahkannya untuk mendorong proses internalisasi Islamic Center menjadi identitas Islam NTB. Hal itu antara lain dilakukan dengan menghadirkan tokoh-tokoh agama tingkat nasional, terutama ustadz-ustadz yang lagi populer di media. Ada banyak da'i kondang yang sudah hadir ke Islamic Center dalam berbagai kegiatan keagamaan yang diprakarsai oleh pemerintah

\footnotetext{
${ }^{30}$ Peter L. Berger dan Thomas Luckmann, Tafsir Sosial Atas Kenyataan Risalah tentang Sosiaologi Pengetahuan (Jakarta: LP3ES, 2012), hlm. 177.
} 
provinsi Nusa Tenggara Barat, seperti Ustadz Arifin Ilham, Ustadz Yusuf Mansur, Aa' Gim, Ustadz Hanan Attaki, dan Ustadz Adi Hidayat.

Peran penting gubernur TGB. Zainul Majdi dalam mendatangkan para ulama dan ustadz tersebut di atas diungkapkan ketua ta'mir Masjid Hubbul Wathan. Menurutnya keberadaan TGB. sebagai gubernur mempunyai peran penting dalam mendatangkan para ulama dan ustadz-ustadz populer dari tanah air. Karena kedekatan beliau sebagai ulama yang sudah diakui secara nasional mempunyai kedekatan secara emosional dengan ulama-ulama lain di seluruh Indonesia. Tentu beliau memanfaatkan pendekatan silaturrahim. Belum pernah ada cerita ada ulama yang menolak diundang ke Islamic Center. ${ }^{31}$

Bahkan pemerintah provinsi NTB, melalui ketokohan gubernur TGB. Zainul Madjdi juga telah dapat menghadirkan ulama-ulama dari Timur Tengah ke Islamic Center, khususnya dalam kegiatan ritual di bulan ramadhan. Sudah dua ramadhan terakhir ini shalat tarawih di Masjid Hubbul Wathan Islamic Center diimami oleh ulama-ulama dari Timur Tengah. Dari data yang ada di laman Islamic Center, pada bulan ramadhan 1438 H. ada empat orang ulama dari Timur Tengah yang secara bergiliran menjadi imam shalat tarawih yang dilaksanakan di Masjid Hubbul Wathan. Mereka yaitu Syaikh Ezzat Sayyid dari Mesir, Syaikh Moad Doaoik dari Mesir, Prof. Dr. Syaikh Khalid Barakat dari Lebanon, dan Syaikh Ahmad Jalal Abdullah Yahya dari Yordania. Sedangkan pada ramadhan 1439 H. ada dua orang ulama dari Timur Tengah yang menjadi imam shalat tarawih, yaitu Syeikh Izzad Sayyid Rasyid dari Mesir dan Syeikh Ahmad Jalal Abdulloh Yahya dari Jordania. ${ }^{32}$

Sebagaimana diungkapkan ta'mir Masjid Hubbul Wathan Islamic Center, TGB sebagai gubernur juga mempunyai peran sentral dalam mendatangkan imam imam dari Timur Tengah. Karena beliau sebagai alumni al-Azhar Mesir mempunyai

\footnotetext{
${ }^{31}$ Wawancara, tanggal 25 September 2018.

32 http://islamiccenter.ntbprov.go.id/
} 
kedekatan secara emosional dengan ulama-ulama yang diundang menjadi imam di Islamic Center. Sebagai ulama yang kapasitasnya sangat diakui oleh ulama-ulama di Timur Tengah. Pendekatan melalui hubungan personal dan pegaruh beliau sebagai ulama alumni Timur Tengah. Juga tidak terlepas dari kapasitas beliau sebagai gubrnur yang menentukan kebijakan. ${ }^{33}$

Kehadiran para ulama dari Timur Tengah untuk menjadi imam shalat tarawih di Masjid Hubbul Wathan merupakan bagian dari cara pemerintah provinsi mempromosikan keberadaan Islamic Center Nusa Tenggara Barat. Begitu juga dengan kehadiran para ustadz dan da'i yang sedang populer di media, merupakan bagian dari publikasi keberadaan Islamic Center. Kehadiran para ulama dan ustadz di atas menjadi magnet masyarakat muslim dari berbagai wilayah, termasuk dari luar Lombok dan NTB untuk datang ke Islamic Center.

Bukan hanya para ustadz kondang tingkat nasional dan para ulama dari Timur Tengah yang telah hadir di Islamic Center Nusa Tenggara Barat. Tokoh politik nasional paling tinggi, yaitu Presiden Republik Indonesia Ir. Joko Widodo (Jokowi) sudah dua kali hadir di Islamic Center, yaitu pada acara Pembukaan MTQ Nasional XXVI pada hari Sabtu tanggal 31 Juli 2016 pukul 20.40 WITA. yang juga dihadiri para Menteri Kabinet, Gubernur se Indonesia, para duta besar Negara Negara sahabat dan undangan lainnya. Kehadiran Presiden Republik Indonesia Ir. Joko Widodo (Jokowi) yang kedua adalah pada tanggal 23 Nopember 2017 pada saat pembukaan Munas Alim Ulama dan Konferensi Besar Nahdlatul Ulama yang berlangsung dari tanggal 23-25 Nopember 2017. ${ }^{34}$

Kehadiran seorang presiden ke sebuah tempat akan menjadi publikasi tersendiri. Seluruh media cetak maupun elektronik akan fokus memberitakan kehadiran presiden di tempat yang bersangkutan. Begitu juga ketika Presiden Jokowi hadir di Islamic Center, maka peristiwa itu menjadi promosi yang luar biasa

\footnotetext{
${ }^{33}$ Wawancara, tanggal 25 September 2018.

${ }^{34}$ Ibid.
} 
bagi keberadaan Islamic Center NTB karena seluruh media cetak dan elektronik memberitakannya. Bukan hanya jutaan pasang mata masyarakat yang ada di Indonesia saja yang menyaksikan peristiwa tersebut, tetapi juga yang ada di luar negeri. Pada sisi lain, kehadiran presiden di Islamic Center dalam peristiwa keagamaan Islam itu sekaligus juga turut mempromosikan keberadaan Islamic Center sebagai ikon baru Islam bagi Kota Mataram dan Nusa tenggara Barat.

Peran lainnya yang ditunjukkan pemerintah provinsi Nusa tenggara Barat dalam mensosialisasikan dan mempublikasikan Islamic Center sebagai ikon Islam di Mataram dan NTB adalah melalui kegiatan di bulan ramadhan. Pada bulan ramadhan dua tahun terakhir, yaitu ramadhan $1438 \mathrm{H}$. dan ramadhan 1439 H., pemerintah provinsi Nusa Tenggara Barat selalu menyelenggarakan Pesona Khazanah Ramadhan yang dipusatkan di Islamic Center Mataram. Pada ramadhan 1438 H/2017, agendanya mencakup berbagai kegiatan, mulai ritual, dakwah sampai budaya Islami. Tabligh Akbar bersama Ustadz Yusuf Mansur dan Gubernur NTB TGH M. Zainul Majdi pada Kamis, 25 Mei 2017 sore di halaman Islamic Center NTB. Kegiatan ibadah akan berlanjut dengan tarawih, tahjjud qiyamulail akbar 2 Juni, temu para imam besar 16 Juni, tadarus bersama Gubernur NTB pada 26 Mei dan 2,9,16 Juni, dan itikaf 4 dan 18 Juni. Hiburan Islami akan digelar pada 26 Mei hingga 24 Juni. Fashion show 26 Mei-18 Juni, pentas seni budaya 3 dan 17 Juni, dan musik religi 27 Mei-17 Juni, serta takbir seribu cahaya pada 24 Juni. $^{35}$

Pada ramadhan $1439 \mathrm{H}$, pemerintah provinsi Nusa Tenggara Barat juga melaksakan kegiatan Gema Ramadhan 1439 H yang juga dipusatkan di Islamic Center. Selain diisi dengan kegiatan ritual tarawih bersama tiga imam dari Timur Tengah dan i'tikaf dan shalat malam bersama, juga diisi dengan berbagai kegiatan lomba keagamaan dan budaya. Ada tujuh bidang mata lomba yang dilaksanakan, yaitu Kegiatan lomba Gema Ramadhan 1439 H ini

\footnotetext{
${ }^{35}$ http:/ /islamiccenter.ntbprov.go.id/content/agenda-dua
} 
terdiri dari 7 macam mata lomba sebagai berikut. Pertama, Tilawatil Qur'an Tingkat Remaja (umur maksimal 24 tahun 11 bulan 29 hari pada tanggal pelaksanaan lomba). Kedua, Tartil Al-Qur'an tingkat Anak-anak SD (umur maksimal 12 tahun 11 bulan 29 hari pada tanggal pelaksanaan lomba). Ketiga, Qira'at sab'ah Murattal (umur maksimal 44 tahun 11 bulan 29 hari pada tanggal pelaksanaan lomba). Keempat, Tahfizh Cilik 1 Juz (juz 30) (umur maksimal 12 tahun 11 bulan 29 hari pada tanggal pelaksanaan lomba). Kelima, Khottil Qur'an Golongan Hiasan Mushaf (umur maksimal 34 tahun 11 bulan 29 hari pada tanggal pelaksanaan lomba). Keenam, Pildacil tingkat anak-anak SD (umur maksimal 12 tahun 11 bulan 29 hari pada tanggal pelaksanaan lomba). Ketujuh, Syarhil Qur'an Tingkat Remaja (umur maksimal 17 tahun 11 bulan 29 hari pada tanggal pelaksanaan lomba). ${ }^{36}$

\section{Penutup}

Peran kekuasaan dalam mengkonstruksi Islamic Center menjadi identitas Islam pada masyarakat muslim di Lombok diwujudkan dalam dua bentuk, yaitu kebijakan anggaran dalam APBD yang dialokasikan untuk pembangunan Islamic Center, pengelolan Islamic Center dengan membentuk UPT yang berada di bawah struktur birokrasi dari BPKAD Provinsi Nusa tenggara Barat, dan publikasi keberadaan Islamic Center melalui penyelenggaraan berbagai event di tingkat lokal, nasional, dan internasional.

Secara teoritis semakin membuktikan kebenaran pandangan yang menyatakan bahwa identitas sosial itu sepenuhnya merupakan hasil konstruksi, terutama yang dilakukan oleh mereka yang memiliki power (kekuasaan). Dalam konteks konstruksi identitas Islam pada masyarakat Lombok, apa yang dipraktikkan pemerintah provinsi Nusa tenggara Barat dalam bentuk membangun Islamic Center adalah melanjutkan proses yang telah berlangsung pada

\footnotetext{
${ }^{36}$ http:/ /islamiccenter.ntbprov.go.id/content/gema-ramadhan-1439-hmasjid-raya-hubbul-wathan-islamic-center-ntb
} 
masa-masa sebelumnya. Dalam ruang kontestasi identitas, maka proses konstruksi identitas Islam yang dilakukan oleh mereka yang memiliki power akan berakibat pada peminggiran identitas lain yang dianggap bukan genuine.

Pada sisi lain, penelitian ini juga membuktikan bahwa mereka yang memiliki power akan cenderung untuk bersikap hegemonik. Power politik dan intelektual pada sosok gubernur TGB, Zainul Madjdi nampak menghegomoni pikiran dan kesadaran masyarakat muslim di Lombok untuk membenarkan dan menyetujui sepenuhnya pembangunan Islamic Center dengan kemegahan Masjid Hubbul Wathan-nya. Pikiran dan kesadaran masyarakat muslim digiring untuk menerima bahwa mereka membutuhkan simbol yang dapat menjadi kebanggaan diri sebagai masyarakat muslim, yaitu sebuah bangunan masjid yang indah dan megah yang mampu menimbulkan ketakjuban para tamu yang datang ke Lombok dan Nusa tenggara barat. 


\section{DAFTAR PUSTAKA}

Albert Leeman. Internal and External Factors of Socio-Cultural and Socio-Economic Dynamics in Lombok, Zurich: Universitat Zurich, 1989.

Anak Agung Ketut Agung. Kupu-kupu Kuning yang Terbang di Selat Lombok: Lintasan Sejarah Kerajaan Karangasem (1661-1950), Ttp.: Upada Sasatra, 1991.

Bagus Takwim. Akar-Akar Ideologi Pengantar Kajian Konsep Ideologi dari Plato hingga Bourdieu, Yogyakarta: JALASUTRA, 2009.

Barker Chris Barker. Cultural Studies Teori dan Praktik, Yogyakarta: Kreasi Wacana, 2004.

BPS Kota Mataram. Mataram dalam Angka, Mataram: BPS Kota Mataram, 2017.

Depdikbud NTB. Monografi Daerah Nusa Tenggara Barat Jilid I, Jakarta: Proyek Pengembangan Media Kebudayaan Dirjen Kebudayaan Depdikbud, 1977.

Erni Budiwanti. Islam Sasak Wetu Telu Versus Waktu Lima, Yogyakarta: LKiS, 2000.

Fath Zakaria. Mozaik Budaya Orang Mataram, Mataram: Yayasan Sumusmas Al-Hamidy, 1998.

John B. Thompson. Kritik Ideologi Global Teori Sosial Kritis tentang Relasi dan Komunikasi Massa, Yogyakarta: IRCISOD, 2006.

Manuel Castells. The Power of Identity, The Information Age: Economy, Society, and Culture, USA: Blackwell Publishers, 1997.

Peter L. Berger dan Thomas Luckmann. Tafsir Sosial Atas Kenyataan Risalah tentang Sosiaologi Pengetahuan, Jakarta: LP3ES, 2012.

Sudarwan Danim. Menjadi Peneliti Kualitatif, Bandung: Pustaka Setia, 2002. 
Sven Cederroth. The Spell of the Ancestors and the Power of Mekkah: A Sasak Community on Lombok, Goeteborg, Sweeden: ACTA Universitas Gothoburgensis, 1981.

Buku Manual Pembangunan Islamic Center Nusa Tenggara Barat. Perpu No. 3 Tahun 2005 tentang Perubahan atas Undang-Undang No. 32 Tahun 2004 tentang Pemerintahan Daerah.

Undang-Undang No. 12 Tahun 2008 tentang Perubahan Kedua atas Undang-Undang No. 32 Tahun 2004 tentang Pemerintahan Daerah.

Undang-Undang No. 22 Tahun 1999 tentang Pemerintahan Daerah.

Undang-Undang No. 25 Tahun 1999 tentang Perimbangan Keuangan Antara Pemerintah Pusat dan Daerah.

Undang-Undang No. 32 Tahun 2004 tentang Pemerintahan Daerah.

Undang-Undang No. 33 Tahun 2004 tentang Perimbangan Keuangan Antara Pemerintah Pusat dan Pemerintahan Daerah.

Undang-Undang No. 5 Tahun 1974 tentang Pokok-pokok Pemerintahan Daerah.

http:// dutaselaparang.com/politik/pdi-p-sebut-anggaran-ic-ntbbermasalah/

http://islamiccenter.ntbprov.go.id/content/agenda-dua

http://www.gardaasakota.com/2018/06/pad-islamic-centerhubbul-wathan-tahun.html

https://mataram.antaranews.com/berita/9109/pembangunanislamic-center-ntb-dimulai

https:// nasional.tempo.co/read/272706/pungutan-dana-islamiccenter-ntb-dipertanyakan $/$ full\&view $=$ ok

https:/ /www.talikanews.com/islamic-center-telan-biaya-rp-600miliar/

www.ntb.go.id 